\title{
PENGARUH KOMPOSISI BRIKET BIOMASSA KULIT JAGUNG TERHADAP KARAKTERISTIK BRIKET
}

\author{
Nasrul ZA, Leni Maulinda*), Frandika Darma, Meriatna \\ Jurusan Teknik Kimia, Fakultas Teknik Universitas Malikussaleh \\ 24352, Aceh Utara, Indonesia. \\ Email: 13ny_77@yahoo.co.id
}

\begin{abstract}
ABSTRAK
Telah diteliti pemanfaatan limbah biomassa kulit jagung dalam pembuatan briket sebagai energi alternatif. Penelitian ini bertujuan untuk mengkaji proses pembuatan briket arang kulit jagung serta pengaruh temperatur karbonisasi dan persentase perekat terhadap kadar air, kadar abu serta nilai kalor briket arang kulit jagung. Kulit jagung yang digunakan terlebih dahulu dijemur serta dikarbonisasi selama 2 jam lalu dicampur dengan perekat yang kemudian dilakukan pencetakan. Hasil analisa Kadar Air terendah sebesar 1,87\% serta kadar air tertinggi sebesar 3,24\%. Kadar abu tertinggi yaitu 4,37\% sementara kadar abu terendah yaitu 2,74\% Nilai kalor tertinggi sebesar 5.777,7247 cal/gr nilai kalor terendah sebesar $5.349,1874 \mathrm{cal} / \mathrm{gr}$. Hasil ini menunjukan bahwa briket yang dihasilkan telah memenuhi SNI01-6235-2000 sebagai acuan baku mutu briket arang.
\end{abstract}

Kata Kunci: Arang, Briket, Karbonisasi, Kulit Jagung, Perekat.

\section{Pendahuluan}

Indonesia merupakan salah satu negara agraria terbesar di dunia yang memiliki banyak pertanian dan perkebunan. Produktivitas pertanian yang jumlahnya sangat besar adalah jagung. Perkembangan teknologi yang semakin pesat dan juga penambahan jumlah 
penduduk yang pesat menyebabkan peningkatan jumlah konsumsi energi bagi manusia (Purwantana dkk, 2009).

Sejalan dengan peningkatan produksi jagung akan berpengaruh terhadap jumlah limbah kulit jagung yang akan mengalami kenaikan secara signifikan. Tumpukan kulit jagung akan menghasilkan limbah padat yang kerap terlihat di beberapa tempat dan mengakibatkan terganggunya pengelihatan manusia juga tercemarnya lingkungan sekitar. Limbah kulit jagung tersebut biasanya hanya digunakan sebagai bahan pakan ternak dan belum dimanfaatkan secara optimal.

Dapat ditinjau dari kandungan kulit jagung yang tersusun dari 44,08\% senyawa selulosa sehingga berpotensi sebagai bahan baku pembuatan bahan bakar padat dalam bentuk briket arang yang cukup potensial. Berdasarkan nilai kalor atau nilai panas bahan baku biomassa yang akan dimanfaatkan tertera pada Tabel 1.

Tabel 1. Asumsi nilai kalor (Calorific Value) dan kandungan air (Moisture Content) pada biomassa

\begin{tabular}{clcc}
\hline \multirow{2}{*}{ Jenis } & Bahan Baku (Feedstock) & Calorivic Value $(\mathrm{Kkal} / \mathrm{kg})$ & Moisture (\%) \\
\hline \multirow{2}{*}{ Tebu } & Ampas tebu (bagasse) & 1.850 & 50 \\
& Daun dan pucuk tebu (cane) & 3.000 & 30 \\
\hline \multirow{2}{*}{ Kelapa } & Sabut kelapa & 3.300 & 30 \\
& Tempurung kelapa (shell) & 4.300 & 15 \\
\hline \multirow{2}{*}{ Karet } & Batang Replanting karet & 4.400 & 15 \\
& (trunk) & & 12 \\
\multirow{2}{*}{ Padi } & Sekam padi (rice husk) & 3.350 & 50 \\
& Jerami padi & 2.800 & 14 \\
\multirow{2}{*}{ Jagung } & Tongkol Jagung (corn cob) & 3.500 & 40 \\
\hline
\end{tabular}

(Sumber: Tajalli, 2015).

Briket arang merupakan bahan bakar yang mengandung karbon dan kalori yang tinggi serta dapat menyala dalam jangka waktu panjang untuk konsumsi energi. Penelitian ini merujuk pada briket untuk kalangan rumah tangga sehingga perlu diperhatikan beberapa hal dikarenakan untuk mencegah polusi udara yang disebabkan dari asap pembakaran. Kualitas briket berdasarkan SNI 01-6235-2000 dapat dilihat pada Tabel 2. 
Tabel 2. Karakteristik briket bioarang berdasarkan SNI 01-6235-2000

\begin{tabular}{cc}
\hline Parameter & Nilai \\
\hline Kadar Air (\%) & 8 \\
\hline Kadar Zat Menguap (\%) & 15 \\
\hline Kadar Abu (\%) & 8 \\
\hline Kadar Karbon Terikat (\%) & 77 \\
\hline Nilai Kalor (Cal/gr) & 5.000 \\
\hline
\end{tabular}

\section{Bahan dan Metode}

\subsection{Bahan}

Bahan-bahan yang digunakan pada penelitian ini adalah serbuk kulit jagung dengan ukuran 20 mesh yang sudah dikarbonasi pada suhu 350, 400, 450 dan $500^{\circ} \mathrm{C}$ selama 2 jam. Larutan kanji sebagai perekat dibuat dengan melarutkan tepung kanji pada aquades dengan perbandingan 1:3 pada penelitian ini.

\subsection{Metode}

Percobaan pembriketan dilakukan dengan mecampurkan arang kulit jagung sebesar 30 gram dengan perbandingan perekat (\%) 2,5, 5, 7,5 dan 10 dari berat arang yang dimasukkan ke dalam wadah kemudian ditekan sampai briket memadati ruang wadah. Briket yang telah terbentuk sempurna lalu dipanaskan di dalam oven pada suhu $60^{\circ} \mathrm{C}$ selama 3 jam. Untuk analisa, dilakukan dengan 3 tahap analisa yaitu menguji kadar air pada persamaan (1), kadar abu tertera pada persamaan (2) dan nilai kalor. Untuk nilai kalor digunakan alat untuk mengukur jumlah kalori yaitu bomb calorimeter.

$$
\begin{aligned}
& \text { kadar air }(\%)=\frac{\mathrm{V}\left(\mathrm{W}_{2}-\mathrm{W}_{3}\right)}{\mathrm{W}_{2}-\mathrm{W}_{1}} \times 100 \\
& \text { kadar abu }(\%)=\frac{\left(\mathrm{W}_{2}-\mathrm{W}_{3}\right)}{\mathrm{W}_{2}-\mathrm{W}_{1}} \times 100
\end{aligned}
$$

\section{Hasil dan Pembahasan}

\subsection{Karbonisasi Kulit Jagung}

Karbonisasi dilakukan sebagai upaya untuk menghilangkan kadar air, gas-gas yang mudah menguap serta membentuk karbon melalui peruraian selulosa dan lignin. Perlakuan kulit jagung yang dikarbonisasi lebih mudah terbentuknya karbon dan nilai kalor yang lebih 
tinggi dibandingkan dengan kulit jagung tidak dikarbonisasi. Gambar 1 menunjukkan perubahan fisik pada kulit jagung yang dikarbonisasi warnanya lebih gelap (hitam), hal ini mengindikasikan bahwa bahan dasar pembuatan briket sempurna karena memiliki kandungan selulosa dan lignin yang tinggi didalamnya.

Prinsip proses karbonasi adalah pembakaran biomassa tanpa adanya kehadiran oksigen. Penggunaan perekat tepung kanji selain harganya yang murah dan mudah didapat juga karena perekat ini memiliki kuat tekan dan nilai kalor yang lebih tinggi. Kanji juga merupakan jenis perekat yang memiliki kandungan air dan abu yang rendah serta karbon yang lebih tinggi dibandingkan dengan perekat jenis lain (Rahmawati dkk, 2013).

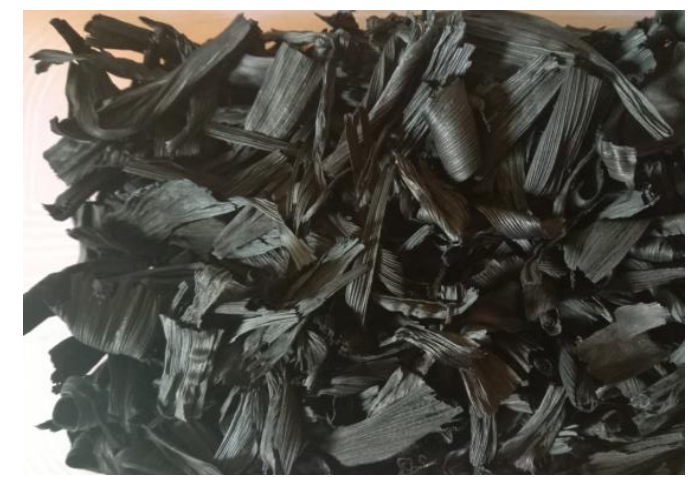

Gambar 1. Kulit jagung yang telah dikarbonisasi

\subsection{Pengaruh Temperatur Karbonisasi dan Persentase Perekat Terhadap Kadar Air Briket Arang Kulit Jagung}

Perhitungan kadar air bertujuan untuk mengetahui sifat higroskopis briket arang kulit jagung yang dihasilkan. Briket arang memiliki sifat higroskopis yang tinggi, sehingga jika dibiarkan di udara terbuka maka briket akan menyerap air dari udara sekitar sehingga menyebabkan briket menjadi rapuh. Kadar air yang dianalisa dalam pembuatan briket ini merupakan kandungan air bebas dari briket. Kandungan air bebas dapat hilang dengan melakukan penguapan atau pengeringan pada suhu $105^{\circ} \mathrm{C}$ selama 2 jam. 


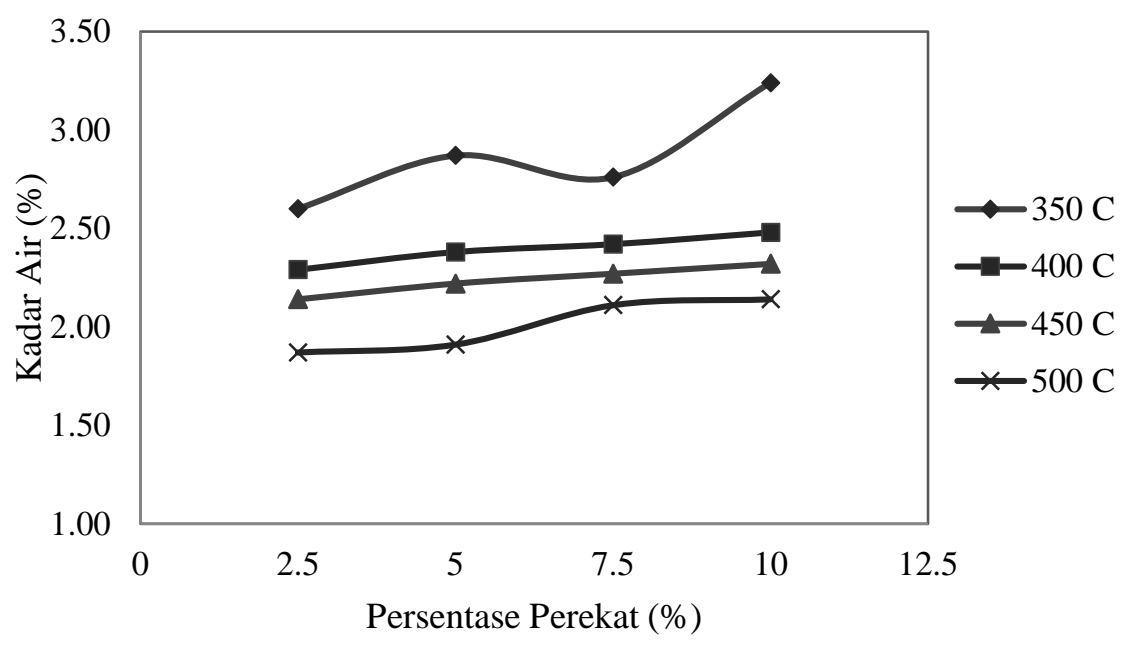

Gambar 2. Pengaruh temperatur karbonisasi serta persentase perekat terhadap kadar air briket arang kulit jagung

Gambar 2 menjelaskan bahwa nilai kadar air pada briket arang kulit jagung semakin meningkat seiring dengan meningkatnya penambahan persentase perekat tapioka meskipun ada sebagian kecil titik yang menunjukan penurunan nilai kadar air. Hal ini disebabkan oleh sifat perekat kanji dan arang yang tidak tahan terhadap kelembaban sehingga mudah menyerap air dari udara.

Semakin tinggi temperatur karbonisasi yang diberikan maka semakin kecil pula kadar air dalam briket tersebut. Hal ini terlihat bahwa kadar air terendah pada temperatur karbonisasi $500^{\circ} \mathrm{C}$ dan persentase perekat $2,5 \%$ yaitu sebesar $1,87 \%$ serta kadar air tertinggi terdapat pada briket dengan variasi temperatur karbonisasi $350^{\circ} \mathrm{C}$ dan persentase perekat $10 \%$ yaitu sebesar 3,24\%. Berdasarkan SNI 01-6235-2000, kadar air maksimal yaitu 8\% sehingga dapat disimpulkan bahwa briket arang kulit jagung telah memenuhi standart tersebut.

\subsection{Pengaruh Temperatur Karbonisasi dan Persentase Perekat Terhadap Kadar Abu Briket Arang Kulit Jagung}

Penentuan kadar abu dilakukan dengan tujuan untuk mengetahui bagian yang tidak terbakar yang sudah tidak memiliki unsur karbon setelah briket dibakar. Gambar 3 memperlihatkan bahwa tingginya kadar abu dalam briket arang kulit jagung semakin meningkat seiring dengan bertambahnya substitusi persentase perekat tepung tapioka yang 
digunakan. Hal ini dikarenakan adanya kandungan abu pada perekat tersebut sehingga menambah kadar abu dari briket yang dihasilkan.

Kadar abu tertinggi yaitu 4,37\% pada temperatur karbonisasi $350^{\circ} \mathrm{C}$ dengan substitusi perekat sebanyak $10 \%$ sementara kadar abu terendah yaitu 2,74\% yang diperoleh dari perlakuan temperatur karbonisasi $500^{\circ} \mathrm{C}$ serta substitusi perekat $2,5 \%$. Ini menunjukan bahwa hasil dari analisa kadar abu pada briket arang kulit jagung memenuhi SNI untuk kadar abu briket yaitu minimal $8 \%$.

Terjadinya penurunan kadar abu pada sustitusi perekat $7,5 \%$ pada temperatur karbonisasi $350^{\circ} \mathrm{C}$ dan $450^{\circ} \mathrm{C}$ dikarenakan terlepasnya mineral yang berpotensi jadi abu pada proses karbonisasinya. Penurunan ini disebabkan karena arang hasil karbonisasi memiliki kerapatan yang sedikit lebih tinggi dibandingkan briket dengan substitusi perekat lainnya serta adanya perbedaan kandungan bahan organik yang terdapat dalam bahan baku kulit jagung pada tiap sampelnya.

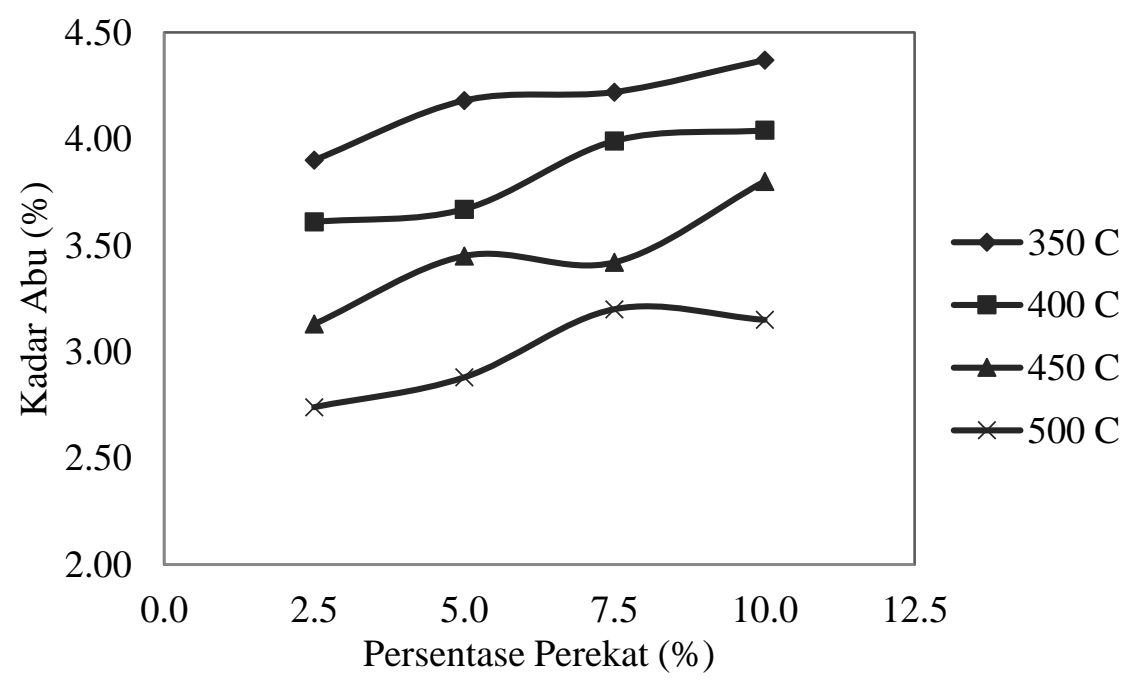

Gambar 3. Pengaruh temperatur karbonisasi dan persentase perekat terhadap kadar abu briket arang kulit jagung

\subsection{Analisa Nilai Kalor Briket Arang Kulit Jagung}

Gambar 4 menjelaskan bahwa penurunan nilai kalor briket arang kulit jagung dapat terjadi seiring dengan bertambahnya persentase perekat yang digunakan. Hal ini disebabkan karena semakin tinggi persentase perekat yang digunakan maka kadar air serta kadar abu dari briket tersebut akan semakin meningkat. Nilai kalor tertinggi sebesar 5.777,7247 cal/gr 
diperoleh pada persentase perekat 2,5\% sementara nilai kalor terendah sebesar 5.349,1874 cal/gr diperoleh pada persentase $10 \%$.

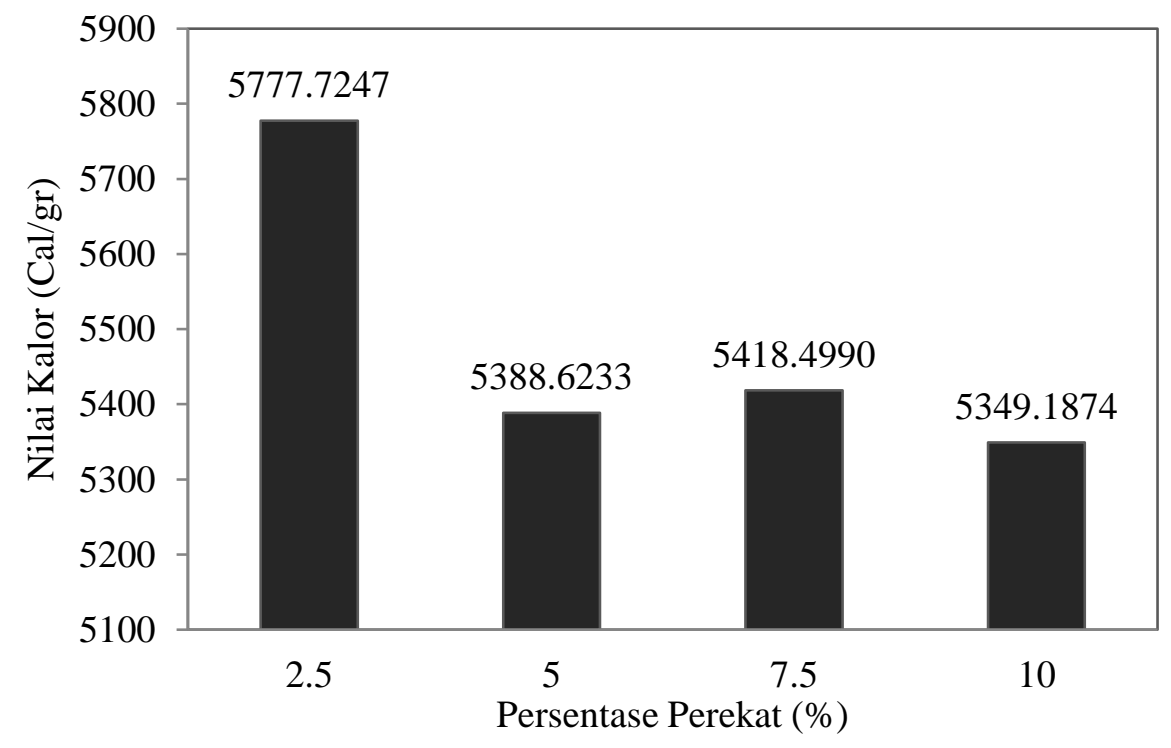

Gambar 4. Hasil analisa nilai kalor briket arang kulit jagung dengan termperatur karbonisasi $500^{\circ} \mathrm{C}$

Kenaikan nilai kalor pada persentase perekat 7,5\% kemingkinan besar terjadi karena sedikit lebih tingginya kerapatan briket tersebut dibandingkan dengan hasil briket pada persentase perekat $5 \%$. Nilai kerapatan yang tinggi akan mempengaruhi nilai kalor dari briket yang dihasilkan. Nilai kalor yang diperoleh untuk briket arang kulit jagung pada temperatur karbonisasi $500^{\circ} \mathrm{C}$ ini telah memenuhi SNI untuk briket arang karena diatas 5000 $\mathrm{cal} / \mathrm{gr}$.

\section{Kesimpulan dan Saran}

Kadar Air terendah diperoleh pada temperatur karbonisasi $500^{\circ} \mathrm{C}$ dan persentase perekat $2,5 \%$ yaitu sebesar $1,87 \%$ serta kadar air tertinggi terdapat pada briket dengan variasi temperatur karbonisasi $350^{\circ} \mathrm{C}$ dan persentase perekat $10 \%$ yaitu sebesar $3,24 \%$ telah memenuhi SNI 01-6235-2000 dengan maksimal 8\%.

Kadar abu tertinggi yaitu 4,37\% pada temperatur karbonisasi $350^{\circ} \mathrm{C}$ dengan substitusi perekat sebanyak $10 \%$ sementara kadar abu terendah yaitu 2,74\% yang diperoleh dari perlakuan temperatur karbonisasi $500^{\circ} \mathrm{C}$ serta substitusi perekat $2,5 \%$ telah memenuhi SNI 01-6235-2000 dengan maksimal 8\%. 
Nilai kalor tertinggi sebesar 5.777,7247 cal/gr diperoleh pada temperatur karbonisasi $500^{\circ} \mathrm{C}$ serta persentase perekat $2,5 \%$ sementara nilai kalor terendah sebesar 5.349,1874 $\mathrm{cal} / \mathrm{gr}$ diperoleh padatemperatur karbonisasi $500^{\circ} \mathrm{C}$ serta persentase $10 \%$ telah memenuhi 01-6235-2000 dengan minimal $5.000 \mathrm{cal} / \mathrm{gr}$.

Penelitian ini dapat dilanjutkan dengan mengganti perekat jenis lain serta persentase perekat yang lain agar dapat melihat karakteristik dari tiap-tiap perekat tersebut serta kondisi optimum pada briket yang dihasilkan.

\section{Daftar Pustaka}

1. Amin, Ahmad Zaenul. 2017. Pengaruh Jumlah Perekat Tepung Tapioka Terhadap Karakteristik Briket Arang Tempurung Kelapa. Jurusan Teknik Mesin Fakultas Teknik UNNES: Semarang.

2. Contaned Energy Indonesia 270190 460933. (n.d.). Buku Panduan ENERGI yang Terbarukan. ISBN 1-885203-29-2.

3. Hendra, djeni \& Winarni, Ina. 2003. Sifat Fisis Dan Kimia Briket Arang Campuran Limbah Kayu Gergaji Dan Sabetan Kayu. Buletin Hasil Penelitian Hasil Hutan Vol. 21 tahun 2003: 211-226.

4. Kalsum, Ummi. 2016. Pembuatan Briket Arang dari Campuran Limbah Tongkol Jagung, Kulit Durian Dan Serbuk Gergaji Menggunakan Perekat Tapioka. Jurnal Distilasi Vol. 1 No. 1 Hal. 42-50.

5. Widodo, T. W., Asari, A., \& Elita, A. N. (2007). Bio Energi Berbasis Jagung dan Pemanfaatan Limbahnya (Bio- Energy (Corn based) and The Utilization Its Waste).Balai Besar Pengembangan Mekanisasi Pertanian Serpong Badan Litbang Pertanian, Departemen Pertanian Tromol Pos 2, 1-13.

6. Yuliah, Yayah., Suryaningsih, Sri., dan Ulfi, Khoirimah. 2017. Penentuan Kadar Air Hilang dan Volatile Metter pada Bio-Briket dari Campuran Arang Sekam Pada dan Batok Kelapa. Jurnal Ilmu dan Inovasi Fisika Vol. 01. No. 01. 51-57. Universitas Padjajaran. 